\title{
Long-range transport of particulate polycyclic aromatic hydrocarbons at Cape Hedo remote island site in the East China Sea between 2005 and 2008
}

\author{
Kei Sato • Hong Li • Yurie Tanaka • Shiho Ogawa • \\ Yuka Iwasaki • Akinori Takami • Shiro Hatakeyama
}

Received: 25 February 2009 / Accepted: 31 August 2009 /

Published online: 16 September 2009

C The Author(s) 2009. This article is published with open access at Springerlink.com

\begin{abstract}
Particle-associated polycyclic aromatic hydrocarbons (PAHs) in outflow from East Asia were observed at Cape Hedo, Okinawa, Japan between 2005 and 2008. The filter samples of the total suspended particles were analyzed by means of gas chromatographymass spectrometry. The total concentration of fourteen 3-7-ring PAHs was $0.01-24 \mathrm{ng} \mathrm{m}^{-3}$ (average $1.6 \mathrm{ng} \mathrm{m}^{-3}$ ). The average $\mathrm{PAH}$ concentration increased in the winter-spring season and decreased in the summer-fall season. The average benzo(a)pyrene to benzo(e)pyrene ratio was 0.49 in the winter-spring season and was lower than the literature values for East Asian cities in the same season. This result shows that aging of organic aerosol particles proceeds during long-range transport from East Asia. In the Asian Pacific region, these pollutants are transported from East Asia in the winter-spring season, whereas clean air mass is transported from the Pacific Ocean in the summer-fall season.
\end{abstract}

K. Sato $\cdot$ A. Takami $\cdot$ S. Hatakeyama

Asian Environment Research Group, National Institute for Environmental Studies, 16-2 Onogawa, Tsukuba, Ibaraki 305-8506, Japan

K. Sato $(\bowtie) \cdot H$. Li $\cdot$ S. Hatakeyama

Atmospheric Environment Division, National Institute for Environmental Studies, 16-2 Onogawa, Tsukuba, Ibaraki 305-8506, Japan

e-mail: kei@nies.go.jp

H. Li

Chinese Research Academy of Environmental Sciences, Lishuiqiao, Anwai, Beijing 100012, China

Y. Tanaka $\cdot$ S. Ogawa $\cdot$ S. Hatakeyama

Graduate School of Life and Environmental Sciences, University of Tsukuba, 1-1-1 Tennodai, Tsukuba 305-8577, Japan

Y. Iwasaki · S. Hatakeyama

Tokyo University of Agriculture and Technology, 3-5-9 Saiwai-cho, Fuchû, Tokyo 183-8509, Japan

Present Address:

K. Sato

Atmospheric Processes Laboratory, Bourns College of Engineering-Center for Environmental Research \& Technology, University of California, Riverside, 1084 Columbia Ave., Riverside, CA 92507, USA 
Keywords East Asia · Asian Pacific region - Air pollution · Atmospheric Brown Clouds-Asia · Organic aerosol · Long-range transport · Photochemical aerosol aging · Secondary organic aerosol formation

\section{Introduction}

Polycyclic aromatic hydrocarbons (PAHs) are mainly during from incomplete combustion and are observed as particulate pollutants accompanied with soot particles (Butler and Crossley 1981). Some PAHs are reported to be mutagenic and carcinogenic (Finlayson-Pitts and Pitts 1999). Since East Asia is the world's largest coal-burning region, PAHs are predicted to have a major impact on atmospheric quality in this region (Lee et al. 2006). The ambient PAH levels reported in East Asian cities are $1.7-553 \mathrm{ng} \mathrm{m}^{-3}$ (Zheng et al. 1997; Park et al. 2002; Chiang et al. 2003; Guo et al. 2003; Tang et al. 2005; Okuda et al. 2006; Wang et al. 2006; Duan et al. 2007; Kume et al. 2007). In particular, PAHs are observed at their highest levels in Chinese megacities in the winter-spring season (Wang et al. 2006).

In the winter-spring season, the pollutants emitted in East Asian cities are transported to the Pacific Ocean by the northeast monsoon. Recently, Zhang et al. (2007) observed organic aerosol at both urban sites (e.g., Beijing, China) and remote sites [e.g., Jeju, South Korea (1,100 km from Beijing) and Okinawa, Japan (1,800 km from Beijing) in the East China Sea (Fig. 1)] using Aerodyne Aerosol Mass Spectrometers (AMSs). The oxygenated organic aerosol (OOA) to organic aerosol $(\mathrm{OA})$ ratio was higher in remote islands than in urban air. They suggested that aged continental aerosol was being observed at these remote island sites. However, AMS cannot provide molecular-level data, so is unable to show direct evidence as to which organic aerosol observed is chiefly continental. Since PAHs are emitted from anthropogenic sources, these compounds are often used as molecular markers of continental organic aerosol. Further, it has recently been pointed out that semi-volatile PAHs are important precursors of secondary organic aerosol in urban air (Chan et al. 2009). Studies of particle-associated PAHs in this region will provide molecular-level evidence of long-range transport of continental organic aerosol.

In 2001-2002, intensive observations of PAHs in the Asian Pacific region were performed during the Asian Pacific Regional Aerosol Characterization Experiment (ACEAsia) campaign (Simoneit et al. 2004). The total PAH concentration was $0.05-7.78 \mathrm{ng} \mathrm{m}^{-3}$ at Jeju Island, and evidence of PAH transport from East Asian cities was found. However, a very small amount of PAHs $\left(0.0-0.078 \mathrm{ng} \mathrm{m}^{-3}\right)$ was observed at Chichi-Jima Island, located in the northwest Pacific Ocean (2,400 km from Beijing: Fig. 1). After these observations, routine observations were carried out on Jeju between 2001 and 2004 (Lee et al. 2006) and Chichi-Jima between 2002 and 2003 (Kaneyasu et al. 2005); the PAH levels observed during the ACE-Asia campaign were confirmed from these routine observations. To obtain better understanding, additional data will be necessary from other observation sites in the Asian Pacific region.

In this study, we observed particle-associated PAHs at Cape Hedo Atmosphere and Aerosol Measurement Station (CHAAMS, $128.3^{\circ} \mathrm{E}, 26.9^{\circ} \mathrm{N}$ ), Okinawa, Japan between 2005 and 2008. This site is determined as a super site for the Atmospheric Brown CloudsAsia (ABC) project because its location is suitable for the observation of outflow from East Asia with negligible interference from local emission sources (Takami et al. 2007). Previously, Primbs et al. (2007) observed particulate PAHs at the same site in Spring 2004. In this study, we observe seasonal changes in the PAH concentrations and study long-range 
Fig. 1 Regional map showing sampling location on Okinawa, Japan and four air mass source regions [China $(\mathrm{CH})$, JapanKorea-Russia (JKR) and the Pacific Ocean (PO)]

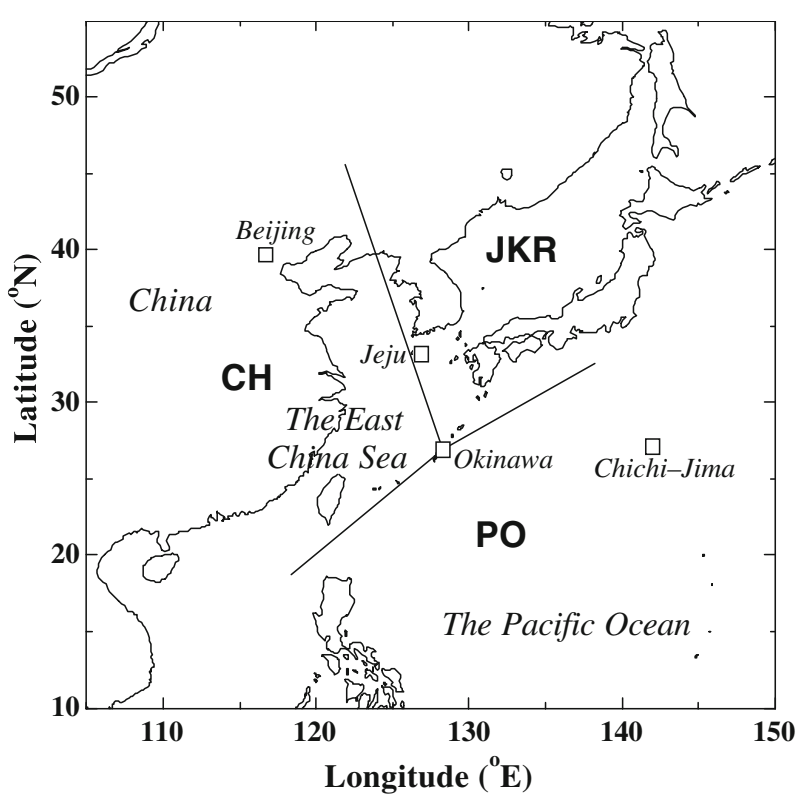

transport by using these seasonal change data. Recently, we reported preliminary results between 2005 and 2006 using HPLC-ultraviolet absorption method (Sato et al. 2007). In this study, we employ gas chromatography-mass spectrometry (GC-MS) and provide a larger dataset between 2005 and 2008. The aims of this study are (i) to understand the temporal levels of PAHs in the East China Sea, (ii) to discuss the photochemical aging of organic aerosol from PAH molecular distribution and (iii) to show long-range transport of continental organic aerosol to the East China Sea.

\section{Experimental method}

Nine intensive measurements were performed between 2005 and 2008. Measurement periods, meteorological data and concentrations of total suspended particles (TSP) are shown in Table 1. Before sampling, quartz fiber filters (Advantec, QR-100) were heated at $773 \mathrm{~K}$ for $4 \mathrm{~h}$ in order to remove any organic contaminants. Aerosol particles were collected on a quartz fiber filter using a high-volume air sampler (Shibata, HV-1000F). The flow rate of the sampler was $1 \mathrm{~m}^{3} \mathrm{~min}^{-1}$. The sampling duration of each sample was $12 \mathrm{~h}$ between 2005 and 2006; daytime and nighttime measurements were carried out separately in these observations. Between 2007 and 2008, the sampling duration of each sample was 24-48 h. Filter samples were stored at $255 \mathrm{~K}$ until their pretreatment. The concentration of TSP was determined from the difference between a filter's weight before and after sampling. The TSP concentration was $14-195 \mu \mathrm{g} \mathrm{m}^{-3}$ over the period of this study.

For pretreatment, each filter sample was cut into small pieces. The filter pieces were extracted by sonication in $50-70 \mathrm{~mL}$ dichloromethane three times and were then extracted in $60 \mathrm{~mL}$ methanol two times. The duration of each sonication was $20 \mathrm{~min}$. Extract placed in a $300-\mathrm{mL}$ round-bottomed flask was concentrated to about $3 \mathrm{~mL}$ under $219 \mathrm{hPa}$ and at $304 \mathrm{~K}$ in a rotary evaporator (Shibata, Tokyo, Japan). Insoluble particles in the extract were removed using a PTFE syringe filter (Whatman, $0.2 \mu \mathrm{m}$ pore size). The extract was replaced 
Table 1 Observation periods, meteorological data and total suspended particle (TSP) concentrations

\begin{tabular}{|c|c|c|c|c|c|c|c|}
\hline Period & $\mathrm{N}$ & $\begin{array}{l}\text { Temperature } \\
\left({ }^{\circ} \mathrm{C}\right)\end{array}$ & $\begin{array}{l}\mathrm{RH} \\
(\%)\end{array}$ & $\begin{array}{l}\text { Wind Speed } \\
\left(\mathrm{m} \mathrm{s}^{-1}\right)^{\mathrm{a}}\end{array}$ & $\begin{array}{l}\text { Prevailing } \\
\text { wind }\end{array}$ & $\begin{array}{l}\text { Pressure } \\
(\mathrm{hPa})\end{array}$ & $\begin{array}{l}\text { TSP } \\
\left(\mu \mathrm{g} \mathrm{m}^{-3}\right)^{\mathrm{a}}\end{array}$ \\
\hline \multicolumn{8}{|l|}{2005} \\
\hline $\begin{array}{l}\text { Dec 6-Dec } 15 \\
2006\end{array}$ & 17 & 16.9 & 62 & $0.8-8.2(4.3)$ & $\mathrm{N}$ & 1022 & $27-117(63)$ \\
\hline Mar 16-Mar 21 & 11 & 18.2 & 66 & $0.1-9.1(3.8)$ & $\mathrm{NE}$ & 1015 & 34-195 (119) \\
\hline Apr 4-Apr 13 & 19 & 21.4 & 76 & $0.0-9.3(4.1)$ & SE & 1013 & $25-11(61)$ \\
\hline $\begin{array}{l}\text { Jun 19-Jun } 22 \\
2007\end{array}$ & 6 & 28.0 & 78 & $0.1-5.8(1.9)$ & SSE & 1013 & $14-17(15)$ \\
\hline Mar 20-Mar 23 & 3 & 18.8 & 70 & $0.3-7.7(2.9)$ & $\mathrm{NNE}$ & 1021 & $22-43(34)$ \\
\hline $\begin{array}{l}\text { Apr 17-Apr } 27 \\
2008\end{array}$ & 10 & 20.9 & 73 & $0.2-9.8(3.6)$ & ENE & 1014 & $24-163(60)$ \\
\hline Mar 25-Apr 4 & 10 & 19.2 & 67 & $0.1-7.6(3.6)$ & NNE & 1015 & $44-111(67)$ \\
\hline Jun 9-Jun 19 & 8 & 27.4 & 80 & $0.4-8.2(4.2)$ & $\mathrm{S}$ & 1011 & $10-60(28)$ \\
\hline Oct $22-$ Oct 31 & 7 & 24.4 & 71 & $0.0-7.1(2.5)$ & $\mathrm{NNE}$ & 1017 & 18-79 (39) \\
\hline Entire Period & 91 & 21.7 & 71 & $0.0-9.8(3.6)$ & ENE & 1015 & $14-195(60)$ \\
\hline
\end{tabular}

${ }^{\text {a }}$ Values in parentheses are averages

in a $20-\mathrm{mL}$ glass vial and was re-concentrated to near dryness under a gentle stream of nitrogen gas. Concentrated extract was dissolved in $1 \mathrm{~mL}$-hexane. The aerosol sample was separated using a flash chromatograph (Biotage, Isolute VacMaster-10) equipped with a disposable silica gel column (Biotage, Isolute SI). By using (i) hexane (15 mL), (ii) hexane/toluene $(5: 3,15 \mathrm{~mL})$, (iii) hexane/dichloromethane $(1: 1,15 \mathrm{~mL})$, (iv) hexane/ethyl acetate $(2: 3,20 \mathrm{~mL})$ and $(\mathrm{v})$ formic acid/methanol $(4: 96,20 \mathrm{~mL})$ as eluents, the molecules in a sample were separated into five fractions. The first fraction was concentrated under a gentle stream of nitrogen gas, then dissolved in 1-mL hexane for use as an analytical sample for PAHs.

A $1-\mu \mathrm{L}$ aliquot of the first fraction sample was injected into a gas chromatograph (Agilent, 6890N) in splitless mode. The temperature of the injection port was $553 \mathrm{~K}$. The injected sample was separated by a capillary column (Agilent J \& W, HP-5MS, length= $30 \mathrm{~m}$ length, diameter $=250 \mu \mathrm{m}$, firm thickness $=0.25 \mu \mathrm{m}$ ). Helium was used as the carrier gas. The flow rate of the carrier gas was $1.0 \mathrm{~mL} \mathrm{~min}^{-1}$. The temperature of the column was maintained at $333 \mathrm{~K}$ for a retention time region of $0-2 \mathrm{~min}$ and was heated from $333 \mathrm{~K}$ to $573 \mathrm{~K}$ for a retention time region of $2-32 \mathrm{~min}$. The separated analytes were introduced into a mass spectrometer (JEOL Ltd., Tokyo, Japan, JMS-700K II) and were ionized by electron ionization. Molecular ions of PAH were monitored using the selected-ion monitor method. Fourteen PAHs [phenanthrene (Phe), anthracene (Ant), fluoranthene (Fla), pyrene (Pyr), benz(a)anthracene $(\mathrm{BaA})$, chrysene $(\mathrm{Chr})$, benzo(e)pyrene $(\mathrm{BeP})$, benzo(b)fluoranthene $(\mathrm{BbF})$, benzo(k)fluoranthene $(\mathrm{BkF})$, benzo(a)pyrene $(\mathrm{BaP})$, dibenz(a,h)anthracene (DBA), benzo(g,h,i)perylene (BghiP), indeno(1,2,3-cd)pyrene (Ind) and coronene (Cor)] were selected as target molecules.

The calibration curves of the selected PAHs were measured in an injection mass region of $<1 \mathrm{ng}$ by diluting a mixed authentic standard sample (Supelco, Custom Mix, $20 \mu \mathrm{g} \mathrm{mL} \mathrm{m}^{-1}$ each). Linear correlation coefficients between the signal intensity and the injection mass were $>0.95$. Lower detection limits were $3-20 \mathrm{pg}$. To check for contamination during 
pretreatment, a blank test was carried out for every intensive observation. No chromatographic peak of PAHs was detected in the analysis of any of the blank samples. To determine the recoveries of target PAHs, a recovery check was performed by analyzing a quartz fiber filter onto which a mixed standard sample $\left(0.25 \mu \mathrm{g} \mathrm{mL} \mathrm{m}^{-1}\right.$ each, $\left.1 \mathrm{~mL}\right)$ was spiked. The recoveries were $45 \pm 35 \%$ (Ant), 56 $\pm 26 \%$ (Phe) and $100 \pm 15 \%$ (other 12 PAHs), here the errors are standard deviations obtained from six measurements. These recoveries were used for corrections of PAH concentrations. For validation of the present analytical methods, PAHs present in a standard reference material sample (NIST SRM 2585 , organic contaminants in house dust) were analyzed. The average of the concentration determined for each PAH molecule agreed with the certified concentration within standard deviations [The number of samples $(\mathrm{N})$ was 4]. The standard deviations of the PAH concentration resulting mainly from the fluctuation of GC-MS signal were less than $15 \%$.

In this study, no internal standard was used for recovery determinations and quantifications. Each result contains the error resulting from the fluctuations of the recovery and the GC-MS signal. The errors were estimated to 79\% (Ant), 48\% (Phe) and $21 \%$ (other 12 PAHs). The errors of Ant and Phe are larger than the others because Ant and Phe are easily vaporized during pretreatments. These errors should be taken into account in interpretation of the present results.

Four-day back trajectories were calculated using NOAA's ARL HYSPLIT 4.0 model (FNL for 2005-2006 and GDAS for 2007-2008) (Draxler and Rolph 2009). For each sample, three trajectories (at 100, 200 and $500 \mathrm{~m}$ altitude above sea level) were calculated at the mean sampling time.

\section{Results and discussion}

\subsection{Seasonal changes of $\mathrm{PAH}$ concentration and $\mathrm{BaP} / \mathrm{BeP}$ ratio}

In this study, 91 filter samples in all were obtained. The range, average and median of total PAH concentration are shown in Table 2. The PAH concentration measured over the entire period was $0.01-23.9 \mathrm{ng} \mathrm{m}^{-3}$. The average PAH concentration $\left(1.6 \mathrm{ng} \mathrm{m}^{-3}\right)$ was higher than the median PAH concentration $\left(0.66 \mathrm{ng} \mathrm{m}^{-3}\right)$, showing that the average was affected by a fairly small number of very high PAH level samples. In this study, at least 9 pollution events were observed in the entire period. The maximum of the total PAH concentration observed during each pollution event was in a range $2.6-24 \mathrm{ng} \mathrm{m}^{-3}$. These total PAH levels were close to or higher than the average levels in Japanese cities [2.6-6.7 $\mathrm{ng} \mathrm{m}^{-3}$ (Simoneit et al. 2004; Tang et al. 2005; Kume et al. 2007)]. The daytime average between 2005 and $2006\left(2.2 \pm 4.6 \mathrm{ng} \mathrm{m}^{-3}, N=28\right)$ was close to the nighttime average for the same period $(1.8 \pm$ $\left.2.8 \mathrm{ng} \mathrm{m}^{-3}, N=24\right)$, indicating that the impact of daytime local human activities on the present results is negligible.

The average of the total PAH concentration increased in the winter-spring season $(2.0 \pm$ $3.9 \mathrm{ng} \mathrm{m}^{-3}$ ) and decreased in the summer-fall season $\left(0.31 \pm 0.59 \mathrm{ng} \mathrm{m}^{-3}\right.$ ) (errors are standard deviations). This results primary from the seasonal changes in the PAH photochemical reaction rates: these increase in summer and decrease in winter. The $\mathrm{BaP} /$ $\mathrm{BeP}$ ratio is often used to study $\mathrm{PAH}$ photochemical aging. $\mathrm{BaP}$ and $\mathrm{BeP}$ are present in automobile exhaust at a ratio of 1:1 (Rogge et al. 1993). Since the lifetime of $\mathrm{BaP}$ is shorter than that of $\mathrm{BeP}$ (Kalberer et al. 2004), the $\mathrm{BaP} / \mathrm{BeP}$ ratio decreases with the elapse of time after the emission of aerosol particles. The ranges and the averages of the $\mathrm{BaP} / \mathrm{BeP}$ ratio are also shown in Table 2. The average of the $\mathrm{BaP} / \mathrm{BeP}$ ratio increased in the winter-spring 
Table 2 Observation periods, total $\mathrm{PAH}$ concentrations and $\mathrm{BaP} / \mathrm{BeP}$ ratios during the present observations

\begin{tabular}{|c|c|c|c|c|c|}
\hline \multirow[t]{2}{*}{ Period } & \multicolumn{3}{|c|}{ Total PAH concentration $\left(\mathrm{ng} \mathrm{m}^{-3}\right)$} & \multicolumn{2}{|l|}{$\mathrm{BaP} / \mathrm{BeP}$} \\
\hline & Range & Average & Median & Range & Average \\
\hline \multicolumn{6}{|l|}{2005} \\
\hline Dec 6-Dec 15 & $0.05-6.6$ & 1.7 & 1.2 & $0.36-0.68$ & 0.50 \\
\hline \multicolumn{6}{|l|}{2006} \\
\hline Mar 16-Mar 21 & $0.69-24$ & 5.5 & 1.5 & $0.42-0.57$ & 0.48 \\
\hline Apr 4-Apr 13 & $0.07-2.6$ & 0.86 & 0.59 & $0.10-0.50$ & 0.37 \\
\hline Jun 19-Jun 22 & $0.01-0.03$ & 0.02 & 0.01 & $0.0-0.48$ & 0.08 \\
\hline \multicolumn{6}{|l|}{2007} \\
\hline Mar 20-Mar 23 & $0.22-0.28$ & 0.25 & 0.24 & $0.39-0.58$ & 0.46 \\
\hline Apr 17-Apr 27 & $0.06-5.9$ & 1.4 & 0.32 & $0.58-0.80$ & 0.69 \\
\hline \multicolumn{6}{|l|}{2008} \\
\hline Mar 25-Apr 4 & $0.28-6.6$ & 1.9 & 1.2 & $0.39-0.70$ & 0.55 \\
\hline Jun 9-Jun 19 & $0.08-0.28$ & 0.14 & 0.11 & $0.31-0.70$ & 0.54 \\
\hline Oct $22-$ Oct 31 & $0.08-2.6$ & 0.77 & 0.30 & $0.34-0.50$ & 0.44 \\
\hline \multicolumn{6}{|c|}{ Summary between 2005 and 2008} \\
\hline Winter-Spring Season & $0.05-24$ & 2.0 & 0.79 & $0.10-0.80$ & 0.49 \\
\hline Summer-Fall Season & $0.01-2.6$ & 0.31 & 0.11 & $0.0-0.70$ & 0.38 \\
\hline Entire Period & $0.01-24$ & 1.6 & 0.66 & $0.0-0.80$ & 0.47 \\
\hline
\end{tabular}

season $(0.49 \pm 0.13)$ and decreased in the summer-fall season $(0.38 \pm 0.23)$ (errors are standard deviations). This indicates that photochemical loss of PAHs in the summer-fall season is greater than in the winter-spring season.

\subsection{Source regions and emission sources}

In the Asian Pacific region, the monsoon from East Asia prevails in the winter-spring season, whereas the monsoon from the Pacific Ocean prevails in the summer-fall season. Thus, the total PAH concentration will also be affected by seasonal changes in the air mass source region. We calculated air mass back trajectories for each sample obtained in this study. The results for a four-day back trajectory are shown in Fig. 2a (spring), b (summer), c (fall) and d (winter). All trajectories calculated at $500 \mathrm{~m}$ were plotted in Fig. 2. Transport from East Asia predominated in winter, whereas that from the Pacific Ocean predominated in summer. Spring and fall were transition seasons, in which transport from both East Asia and the Pacific Ocean was observed. The seasonal change of back trajectory is consistently explained by a typical seasonal change of the monsoon in this region.

Seasonal changes in the emission source strengths of PAHs will also contribute to the seasonal change of the total PAH concentration observed. Atmospheric emission inventory of PAHs was developed for China (Lang et al. 2008) and all countries in the world (Zhang and Tao 2009). According to these results, biomass combustion, coke industry and domestic coal combustion are major PAH emission sources in China. On the other hand, consumer product use, traffic oil combustion and waste incineration are major sources in developed countries such as Japan and South Korea. On the basis of these results, we can presume that the PAH source strengths in China increase in winter due to use of biomass, 


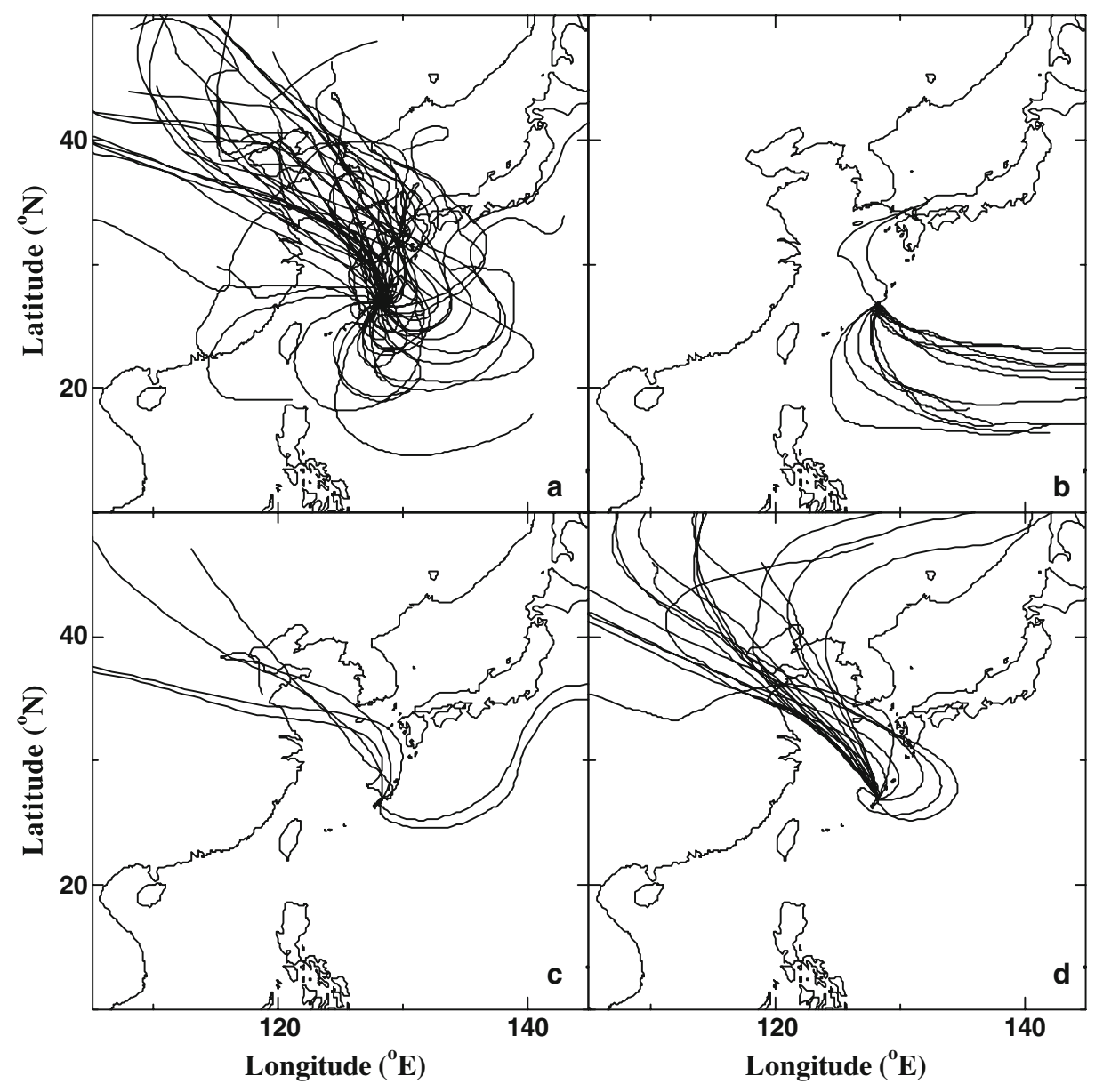

Fig. 2 Four-day back-trajectory analysis results of the a spring $\mathbf{b}$ summer $\mathbf{c}$ fall and $\mathbf{d}$ winter seasons

coke and coal for heating, whereas the source strengths in developed countries are weakly dependent on the season. Actually, the ratios of winter PAH level to summer PAH level in 14 Chinese cities [3.3-45 (Wang et al. 2006)] are higher than those in 4 Japanese cities [1.9-2.6 (Tang et al. 2005)]. The total PAH concentration observed at Cape Hedo is affected by seasonal changes in the PAH photochemical reaction rates, the air mass source region and the source strengths.

The dependence of the total PAH concentration on the air mass source region was studied by using the present data. As defined in Fig. 1, we divided the source region into three divisions [China (CH), the Pacific Ocean (PO) and Japan-Korea-Russia (JKR)]. The source region of each sample was determined by the position of intersection between the trajectory and the shoreline of source region. Trajectories with no intersection were attributed to PO. As for each source region, the averages of the total PAH concentration and the $\mathrm{BaP} / \mathrm{BeP}$ ratio were calculated (Fig. 3). The $\mathrm{BaP} / \mathrm{BeP}$ ratio of $\mathrm{CH}(0.48 \pm 0.10)$ and JKR $(0.50 \pm 0.14)$ were close to each other (errors are standard deviations), showing that PAHs transported from $\mathrm{CH}$ and JKR had aged to a similar extent. The average PAH concentration of $\mathrm{CH}\left(2.9 \pm 4.1 \mathrm{ng} \mathrm{m}^{-3}\right)$ was higher than that of JKR $\left(0.7 \pm 1.1 \mathrm{ng} \mathrm{m}^{-3}\right)$ (errors are standard 


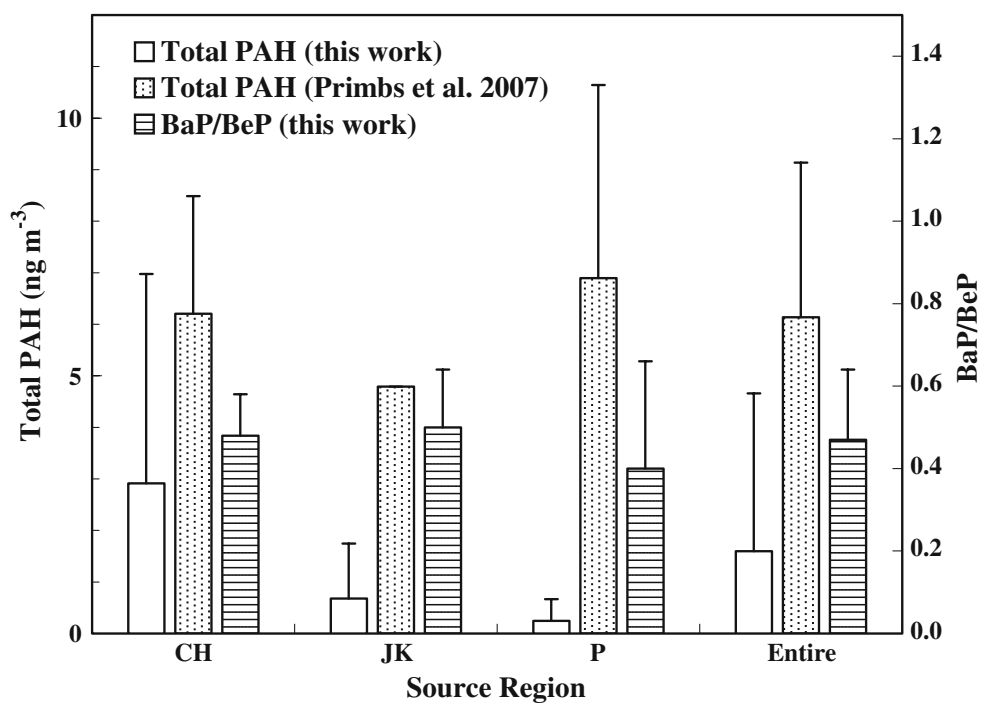

Fig. 3 Dependences of total $\mathrm{PAH}$ concentration and $\mathrm{BaP} / \mathrm{BeP}$ ratio on the air mass source region. For air mass source region, see Fig. 1. The numbers of data attributed to $\mathrm{CH}, \mathrm{JKR}$ and PO are 42,25 and 24 in this work

deviations). This might result from the fact that $\mathrm{CH}$ is the largest $\mathrm{PAH}$ emission area in this region. However, not only the source region but also meteorological conditions will affect resultant PAH concentrations. This is further discussed in the latter section.

The present definition of source region is essentially the same as that employed by Primbs et al. (2007). Figure 3 also plots the results observed at Cape Hedo in spring 2004 by Primbs et al. (2007). The average PAH concentration of PO is the highest of three source regions in this previous study. Their results of PO may be affected by local emission sources. However, no clear evidence of interference from local emission was found in the present study.

\subsection{Spatial distributions of PAH level in Asian Pacific region}

For better understanding of PAH transport in Asian Pacific region, the present data were compared with previous data obtained at other observation sites. The averages of total PAH concentration and the averages of $\mathrm{BaP} / \mathrm{BeP}$ ratio in the winter-spring season are summarized in Table 3. Primbs et al. (2007) observed PAHs at Cape Hedo in spring 2004. The total PAH concentration they observed $\left(6.1 \pm 3.0 \mathrm{ng} \mathrm{m}^{-3}\right)$ was of the same order of magnitude as the present result $\left(1.6 \pm 3.1 \mathrm{ng} \mathrm{m}^{-3}\right)$ (errors are standard deviations). Although the average value measured by Primbs et al. (2007) is higher than that measured in this study, it is not surprising because the sampling periods are different between these two studies. Kaneyasu and Takada (2004) observed PAHs at Amami and Miyako Islands in the East China Sea. The total PAH concentration they observed between 1993 and 1994 $\left(0.45 \pm 0.34 \mathrm{ng} \mathrm{m}^{-3}\right.$ at Amami and $0.44 \pm 0.52 \mathrm{ng} \mathrm{m}^{-3}$ at Miyako) was close to or slightly lower than the present result. We selected the previous results obtained at Jeju between 2001 and 2004 by Lee et al. (2006) for comparison with the present result since their work provides the latest and the largest dataset from past data for the East China Sea. In a similar manner, the results for Beijing between 2003 and 2005 (Okuda et al. 2006) and Chichi-Jima 
Table 3 Averages of total $\mathrm{PAH}$ concentration and average of $\mathrm{BaP} / \mathrm{BeP}$ ratio in the winter-spring season

\begin{tabular}{|c|c|c|c|c|c|c|}
\hline Site & Year & Particle size & $\mathrm{N}$ & 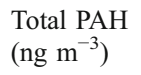 & $\begin{array}{l}\text { Winter-Spring } \\
\mathrm{BaP} / \mathrm{BeP}\end{array}$ & Reference \\
\hline \multicolumn{7}{|l|}{ East China Sea } \\
\hline $\begin{array}{l}\text { Okinawa, } \\
\text { Japan }\end{array}$ & $\begin{array}{l}2005- \\
2008\end{array}$ & TSP (14 PAHs) & 91 & 1.6 & 0.49 & This study \\
\hline $\begin{array}{l}\text { Okinawa, } \\
\text { Japan }\end{array}$ & 2004 & TSP (15 PAHs) & 18 & $6.1^{\mathrm{b}}$ & - & Primbs et al. 2007 \\
\hline Amami, Japan & $\begin{array}{l}1993- \\
1994\end{array}$ & $\mathrm{PM}_{2.5}$ (12 PAHs) & 14 & 0.45 & 0.49 & $\begin{array}{l}\text { Kaneyasu and } \\
\text { Takada } 2004\end{array}$ \\
\hline $\begin{array}{l}\text { Jeju, South } \\
\text { Korea }\end{array}$ & 2001 & TSP (16 PAHs) & 7 & 4.0 & - & Simoneit et al. 2004 \\
\hline $\begin{array}{l}\text { Jeju, Sourth } \\
\text { Korea }\end{array}$ & $\begin{array}{l}2001- \\
2004\end{array}$ & TSP (13 PAHs) & 103 & 3.7 & 0.71 & Lee et al. 2006 \\
\hline Miyako, Japan & $\begin{array}{l}1993- \\
1994\end{array}$ & $\mathrm{PM}_{2.5}$ (12 PAHs) & 15 & 0.44 & 0.54 & $\begin{array}{l}\text { Kaneyasu and } \\
\text { Takada } 2004\end{array}$ \\
\hline \multicolumn{7}{|c|}{ North-West Pacific Ocean } \\
\hline $\begin{array}{l}\text { Chichi-Jima, } \\
\text { Japan }\end{array}$ & $\begin{array}{l}1990- \\
1991\end{array}$ & TSP (16 PAHs) & 3 & 0.03 & - & Simoneit et al. 2004 \\
\hline $\begin{array}{l}\text { Chichi-Jima, } \\
\text { Japan }\end{array}$ & $\begin{array}{l}2002- \\
2003\end{array}$ & $\begin{array}{l}\mathrm{PM}_{2.5} \text { (3-7-ring } \\
\text { PAHs) }\end{array}$ & 19 & 0.11 & 0.15 & $\begin{array}{l}\text { Kaneyasu et al. } \\
2005\end{array}$ \\
\hline \multicolumn{7}{|c|}{ East Asian Cities } \\
\hline Beijing, China & $\begin{array}{l}2003- \\
2005\end{array}$ & TSP (15 PAHs) & 64 & 178 & 0.86 & Okuda et al. 2006 \\
\hline Beijing, China & 2003 & $\mathrm{PM}_{2.5}$ (18 PAHs) & 2 & 108 & 1.17 & Wang et al. 2006 \\
\hline $\begin{array}{l}\text { Changchun, } \\
\text { China }\end{array}$ & 2003 & $\mathrm{PM}_{2.5}$ (18 PAHs) & 2 & 111 & 1.25 & Wang et al. 2006 \\
\hline $\begin{array}{l}\text { Chongqing, } \\
\text { China }\end{array}$ & 2003 & $\mathrm{PM}_{2.5}$ (18 PAHs) & 2 & 361 & 0.83 & Wang et al. 2006 \\
\hline $\begin{array}{l}\text { Guangzhou, } \\
\text { China }\end{array}$ & $\begin{array}{l}2003- \\
2004\end{array}$ & $\mathrm{PM}_{10}(13 \mathrm{PAHs})$ & 11 & 51 & 0.65 & Duan et al. 2007 \\
\hline $\begin{array}{l}\text { Guangzhou, } \\
\text { China }\end{array}$ & 2003 & $\mathrm{PM}_{2.5}$ (18 PAHs) & 2 & 167 & 1.33 & Wang et al. 2006 \\
\hline $\begin{array}{l}\text { Hangzhou, } \\
\text { China }\end{array}$ & 2003 & $\mathrm{PM}_{2.5}(18 \mathrm{PAHs})$ & 2 & 27 & 0.46 & Wang et al. 2006 \\
\hline Hong Kong & 1993 & TSP (15 PAHs) & 6 & 17 & 0.46 & Zheng et al. 1997 \\
\hline $\begin{array}{l}\text { Hong Kong, } \\
\text { China }\end{array}$ & $\begin{array}{l}2000- \\
2001\end{array}$ & $\mathrm{PM}_{2.5}$ (16 PAHs) & 30 & 17 & - & Guo et al. 2003 \\
\hline $\begin{array}{l}\text { Hong Kong, } \\
\text { China }\end{array}$ & 2003 & $\mathrm{PM}_{2.5}$ (18 PAHs) & 2 & 7.9 & 0.78 & Wang et al. 2006 \\
\hline $\begin{array}{l}\text { Jinchang, } \\
\text { China }\end{array}$ & 2003 & $\mathrm{PM}_{2.5}$ (18 PAHs) & 2 & 109 & 0.53 & Wang et al. 2006 \\
\hline $\begin{array}{l}\text { Qingdao, } \\
\text { China }\end{array}$ & 2003 & $\mathrm{PM}_{2.5}$ (18 PAHs) & 2 & 46 & 0.59 & Wang et al. 2006 \\
\hline $\begin{array}{l}\text { Shanghai, } \\
\text { China }\end{array}$ & 2003 & $\mathrm{PM}_{2.5}(18 \mathrm{PAHs})$ & 2 & 46 & 0.75 & Wang et al. 2006 \\
\hline $\begin{array}{l}\text { Shenyang, } \\
\text { China }\end{array}$ & 2001 & TSP (9 PAHs) & 9 & $135^{\mathrm{a}}$ & - & Tang et al. 2005 \\
\hline Tianjin, China & 2003 & $\mathrm{PM}_{2.5}$ (18 PAHs) & 2 & 77 & 0.92 & Wang et al. 2006 \\
\hline Wuhan, China & 2003 & $\mathrm{PM}_{2.5}$ (18 PAHs) & 2 & 60 & 0.42 & Wang et al. 2006 \\
\hline
\end{tabular}


Table 3 (continued)

\begin{tabular}{|c|c|c|c|c|c|c|}
\hline Site & Year & Particle size & $\mathrm{N}$ & 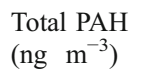 & $\begin{array}{l}\text { Winter-Spring } \\
\mathrm{BaP} / \mathrm{BeP}\end{array}$ & Reference \\
\hline $\begin{array}{c}\text { Xiamen, } \\
\text { China }\end{array}$ & 2003 & $\mathrm{PM}_{2.5}$ (18 PAHs) & 2 & 14 & 0.58 & Wang et al. 2006 \\
\hline Xi'an, China & 2003 & $\mathrm{PM}_{2.5}$ (18 PAHs) & 2 & 403 & 1.15 & Wang et al. 2006 \\
\hline Yulin, China & 2003 & $\mathrm{PM}_{2.5}$ (18 PAHs) & 2 & 103 & 1.21 & Wang et al. 2006 \\
\hline Taiwan & $\begin{array}{l}1990- \\
1998\end{array}$ & TSP (14 PAHs) & 131 & 5.2 & - & Chiang et al. 2003 \\
\hline $\begin{array}{l}\text { Kanazawa, } \\
\text { Japan }\end{array}$ & 1999 & TSP (9 PAHs) & 14 & $2.6^{\mathrm{a}}$ & - & Tang et al. 2005 \\
\hline $\begin{array}{l}\text { Kitakyushu, } \\
\text { Japan }\end{array}$ & 1997 & TSP (9 PAHs) & 20 & $5.0^{\mathrm{a}}$ & - & Tang et al. 2005 \\
\hline $\begin{array}{l}\text { Sapporo, } \\
\text { Japan }\end{array}$ & 1997 & TSP (9 PAHs) & 20 & $5.8^{\mathrm{a}}$ & - & Tang et al. 2005 \\
\hline $\begin{array}{l}\text { Sapporo, } \\
\text { Japan }\end{array}$ & $\begin{array}{l}2001- \\
2002\end{array}$ & TSP (16 PAHs) & 5 & 6.7 & - & Simoneit et al. 2004 \\
\hline $\begin{array}{l}\text { Shizuoka, } \\
\text { Japan }\end{array}$ & $\begin{array}{l}2001- \\
2002\end{array}$ & $\mathrm{PM}_{2.5}$ (21 PAHs) & 12 & 4.2 & 0.92 & Kume et al. 2007 \\
\hline Tokyo, Japan & 1997 & TSP (9 PAHs) & 20 & $6.3^{\mathrm{a}}$ & - & Tang et al. 2005 \\
\hline $\begin{array}{l}\text { Seoul, South } \\
\text { Korea }\end{array}$ & $\begin{array}{l}1998- \\
1999\end{array}$ & TSP (15 PAHs) & 4 & 26 & - & Park et al. 2002 \\
\hline $\begin{array}{l}\text { Vladivostok, } \\
\text { Russia }\end{array}$ & 1999 & TSP (9 PAHs) & 14 & $21^{\mathrm{a}}$ & - & Tang et al. 2005 \\
\hline
\end{tabular}

${ }^{a}$ Original data given in units of $\mathrm{nmol} \mathrm{\textrm {m } ^ { - 3 }}$ were converted by assuming a molecular weight to be $250 \mathrm{~g}$ $\mathrm{mol}^{-1}$. ${ }^{\mathrm{b}}$ Calculated by summing the total concentration of flurorene, Phe, Ant, Fla, Pyr and retene and the total concentration of $\mathrm{BaA}, \mathrm{Chr}, \mathrm{BbF}, \mathrm{BkF}, \mathrm{BeP}, \mathrm{BaP}$, Ind, DBA and BghiP

between 2002 and 2003 (Kaneyasu et al. 2005) were selected as the representative data of East Asian city and the Pacific Ocean, respectively.

The averages of total PAH concentration in the present and previous studies are shown in Fig. 4a. The average total PAH concentration in Beijing, a representative source region, is $178 \pm 240 \mathrm{ng} \mathrm{m}^{-3}$ (error is standard deviation). The average total PAH concentrations at Jeju (3.7 $\left.\pm 4.7 \mathrm{ng} \mathrm{m}^{-3}\right)$ and Cape Hedo $\left(1.6 \pm 3.1 \mathrm{ng} \mathrm{m}^{-3}\right.$, this study; $6.1 \pm 3.0 \mathrm{ng} \mathrm{m}^{-3}$, Primbs et al. 2007) in the East China Sea were lower than those observed in Beijing. The average total PAH concentration at the Chichi-Jima site in the Pacific Ocean is $0.11 \mathrm{ng} \mathrm{m}^{-3}$ and is the lowest in this region. The spatial distribution shown in Fig. 4a suggests that the total PAH level observed at Cape Hedo increases due to transport from East Asia.

Direct evidence of long-range transport of PAHs was obtained by studying the $\mathrm{BaP} / \mathrm{BeP}$ ratio. We compared the average of the $\mathrm{BaP} / \mathrm{BeP}$ ratios in the winter-spring season among four Asian Pacific sites (Fig. 4b). The results of the winter-spring season were compared because transport from East Asia prevails in this season. The average $\mathrm{BaP} / \mathrm{BeP}$ ratio of the winter-spring season decreased with increasing distance from Beijing ( 0.86 at Beijing, 0.71 at Jeju, $0.49 \pm 0.13$ at Cape Hedo and 0.15 at Chichi-jima). PAHs observed at Cape Hedo in the winter-spring season are transported from East Asian cities.

In the above discussion, the $\mathrm{BaP} / \mathrm{BeP}$ ratio is assumed to be constant independent of fuel type, but the $\mathrm{BaP} / \mathrm{BeP}$ ratio may depend on fuel type. Tanaka and Sakata (2002) summarized previous laboratory results of the $\mathrm{BaP} / \mathrm{BeP}$ ratios from various fuels (gasoline, light oil, heavy oil, coal, and wood). They concluded that the $\mathrm{BaP} / \mathrm{BeP}$ ratio is almost 
Fig. 4 Comparisons with recent results for a average of total polycyclic aromatic hydrocarbon concentration and $\mathbf{b}$ average of $\mathrm{BaP} / \mathrm{BeP}$ ratio in the winterspring season. Open symbol represents present result. Filled symbol represents previous result. Data are taken from Okuda et al. (2006) (Beijing, $N=64)$, Lee et al. (2006) (Jeju, $N=103$ ), this study (Okinawa, $N=91$ ), Primbs et al. (2007) (Okinawa, $N=18$ ) and Kaneyasu et al. (2005) (ChichiJima, $N=19$ )

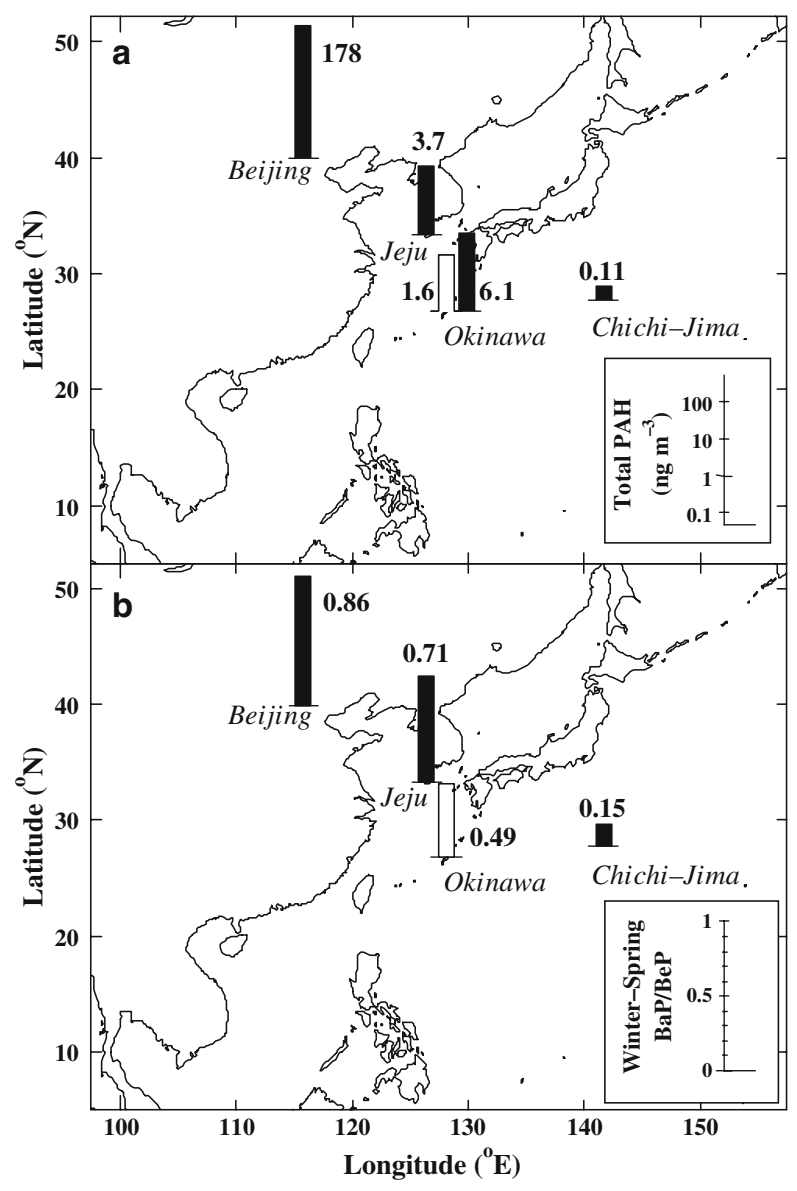

constant independent of the fuel type. Thus, the $\mathrm{BaP} / \mathrm{BeP}$ ratio can safely be used as the index of aerosol aging even if there are various emission sources.

\subsection{PAH molecular distribution at Cape Hedo}

The average PAH molecular distribution is shown in Fig. 5 (error bars represent standard deviations). The concentrations of Phe, Fla, Pyr and BbF were the highest of the fourteen PAHs measured at Cape Hedo, and this tendency was also observed in the molecular distribution measured previously at Cape Hedo (Primbs et al. 2007) and those measured in East Asian cities (e.g., Wang et al. 2006; Okuda et al. 2006). On the other hand, the $\mathrm{BaP} / \mathrm{BeP}$ ratio observed at Cape Hedo is lower than that observed in Beijing as described above. The average of $\mathrm{BaA} / \mathrm{Chr}$ ratio (also used to study photochemical aging) was 0.28 at Cape Hedo in the winter-spring season and was lower than those observed in Beijing [0.74 (Okuda et al. 2006)], Seoul [1.21 (Tang et al. 2005)] and Tokyo [0.69 (Tang et al. 2005)]. The $\mathrm{BaA} / \mathrm{Chr}$ ratio showed a weak correlation with the $\mathrm{BaP} / \mathrm{BeP}$ ratio (the correlation coefficient was 0.14 ). The Ant/Phe ratio is also sometime used to study aerosol aging, but we did not employ this here because the present results of Ant and Phe contained large errors. The concentrations of highly reactive PAHs such as Ant, BaA, 


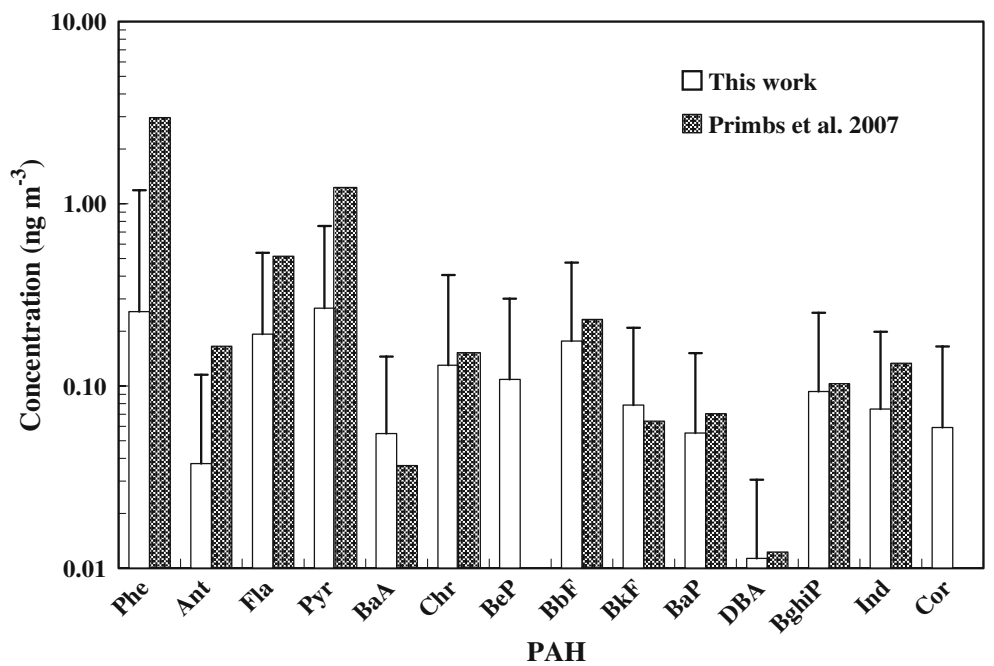

Fig. 5 Averaged molecular distributions of polycyclic aromatic hydrocarbons at Cape Hedo, Okinawa, Japan obtained in this study and previous study (Primbs et al. 2007). The molecular distribution measured by Primbs et al. (2007) was calculated by using their results of the relative PAH distribution and the total PAH concentration. Primbs et al. (2007) did not provide the BeP and Cor data

$\mathrm{BaP}$ and DBA were lower than those of less reactive PAHs, as shown in Fig. 5. The PAH molecular distribution observed in urban air is often used to determine these emission sources. However, we did not discuss the emission sources from our results because the molecular distribution may be significantly changed from the original one due to photochemical aging.

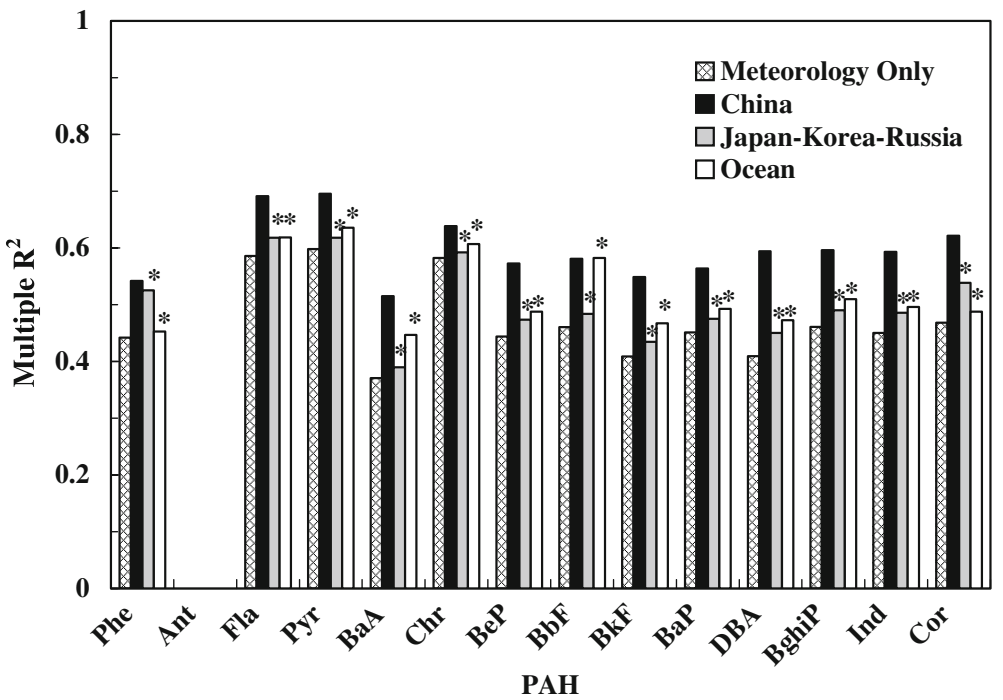

Fig. 6 Results of multivariable linear regression model. A star indicates the slope for the source term was negative (i.e., the PAH concentrations decrease with increasing SRIF) 
The average concentrations of $\mathrm{BaP}$ and $\mathrm{DBA}$ were $55 \pm 96$ and $11 \pm 19 \mathrm{pg} \mathrm{m} \mathrm{m}^{-3}$, respectively (error bars are standard deviations). BaP and DBA are regarded as carcinogenic and probably carcinogenic to humans, respectively (International Agency for Research on Cancer 2009). Since the PAHs observed at Cape Hedo are highly aged by photochemical reactions, the ratio of the potentially carcinogenic PAHs to the total PAH concentration is lower than that in urban air.

\subsection{Meteorological and source region variability}

As mentioned in section 3.2, meteorological conditions as well as the source region will affect resultant PAH concentrations. Primbs et al. (2007) used a multivariable linear regression model to study meteorological and source region variability and concluded that long-range transport of PAHs from China was substantial. We attempted to employ their method for the analysis of the present results.

In order to investigate the differences in the source regions (China, Japan-Korea-Russia and Ocean), source region impact factors (SRIFs) were calculated on the basis of trajectory results. The SRIF represents the percentage of the time an air mass spent in a given source region in the last four days prior to arriving at Cape Hedo (Primbs et al. 2007). Then, the day-by-day concentration data of a specific PAH $(N=91)$ was fitted by the following multivariable linear function:

$$
\begin{aligned}
\log (\text { conc })= & b_{0}+b_{1} J D+b_{2} W S+b_{3} \text { Sun }+b_{4} \cos (W D)+b_{5} \sin (W D)+b_{6} p p t \\
& +b_{7} 1000 / T+b_{8} \text { SRIF. }
\end{aligned}
$$

In Eq. (1), $J D$ represents in Julian Days, $W S\left(\mathrm{~m} \mathrm{~s}^{-1}\right)$ is the site wind speed, Sun $\left(\mathrm{W} \mathrm{m}^{-2}\right)$ is the site sun intensity, WD (rad.) is the average site wind direction, ppt (mm) is the precipitation summed for 4 days back, $T(\mathrm{~K})$ is the average site temperature, SRIF is the source region impact factor of a specific source region and $b_{\mathrm{i}}$ terms $(\mathrm{i}=0-8)$ are coefficients. The summed precipitation was calculated using the HYSPLIT model. The site sun intensity data were provided by SKYNET project (2009).

When the $b_{8}$ term in Eq. (1) was assumed to be zero and the other $b$ terms were treated as fitting parameters (i.e., meteorological variables were only taken into account), the multiple $\mathrm{R}^{2}$ values ( $\mathrm{p}$-value $<0.05$ ) were determined to be $0.37-0.60$ as shown in Fig. 6. The concentrations of PAHs were mainly influenced by temperature and decreased with increasing the temperature. The SRIF were included in the model by treating all the $b$ terms as the fitting parameters. Results of $\mathrm{R}^{2}$ were also shown in Fig. 6. Stars indicate that the resultant $b_{8}$ term is negative, indicating that the PAH concentrations decrease when the air mass came from the stated source region. The concentrations of PAHs increased when the source region was identified as China even after meteorological variables were taken into account.

\section{Conclusions}

In this study, particle-associated PAHs were observed at Cape Hedo between 2005 and 2008. The average of total PAH concentration was $1.6 \mathrm{ng} \mathrm{m}^{-3}$. Total PAH concentration observed at pollution events was 2.6-24 $\mathrm{ng} \mathrm{m}^{-3}$; these total PAH levels were close to or 
higher than the averages for Japanese cities. However, the ratio of potentially carcinogenic PAHs (i.e., BaP and DBA) to the total PAH concentration at Cape Hedo was lower than that in urban air because of photochemical loss of these compounds during long-range transport.

The average PAH concentration increased in the winter-spring season and decreased in the summer-fall season. The average of the benzo(a)pyrene to benzo(e)pyrene ratio was 0.49 in the winter-spring season and was lower than literature values for East Asian cities in the same season. These pollutants are transported by the monsoon from East Asia in the winter-spring season, whereas clean air mass is transported by the monsoon from the Pacific Ocean in the summer-fall season.

The present results show evidence of long-range transport of aged continental organic aerosol at the molecular level. The present results therefore support the recent AMS observation results of long-range transport of aged continental organic aerosol at Jeju and Okinawa Islands (Zhang et al. 2007; Takami et al. 2007).

Acknowledgements K. S. and H. L. thank Professor Kimitaka Kawamura of Hokkaido University for technical advice on pretreatments. The authors thank Dr. Hiroyasu Ito and Mrs. Mayumi Ito at the Laboratory of Intellectual Fundamentals for Environmental Studies, the National Institute for Environmental Studies (NIES), Japan for supplying a GC-MS instrument. The authors thank Dr. Shuichi Hasegawa at the Asian Environment Research Group, NIES, Japan for supplying an electric balance combined with an air conditioner system. The authors thank SKYNET project for supplying solar flux data. The author's thanks are due to NOAA, United States, for their backward trajectory analysis service. H. L. gratefully acknowledges an Eco Frontier Fellowship from the Ministry of the Environment of Japan. This work was supported by an Asian Environment Research Program from NIES, Japan (FY2006-2010), Global Environment Research Fund Projects from the Ministry of the Environment of Japan (B-8, FY2002-2004; C-51, FY2005-2007), a Grant-inAid for Scientific Research from the Ministry of Education, Culture, Sports, Science and Technology of Japan (No. 20120007, FY2008-2012), a Grant-in-Aid for Scientific Research from Japan Society for the Promotion of Science (No. 21510023, FY2009-2011) and an Environmental Research and Technology Development Fund from the Ministry of the Environment of Japan (FY2009-2011).

Open Access This article is distributed under the terms of the Creative Commons Attribution Noncommercial License which permits any noncommercial use, distribution, and reproduction in any medium, provided the original author(s) and source are credited.

\section{References}

Butler, H.T., Crossley, P.: Reactivity of polycyclic aromatic hydrocarbons adsorbed on soot particles. Atmos. Environ. 15, 91-94 (1981)

Chan, A.W.H., Kautzman, K.E., Chhabra, P.S., Surratt, J.D., Chan, M.N., Crounse, J.D., Kürten, A., Wennberg, P.O., Flagan, R.C., Seinfeld, J.H.: Secondary organic aerosol formation from photooxidation of naphthalene and alkylnaphtalenes: implications for oxidation of intermediate volatility organic compounds (IVOCs). Atmos. Chem. Phys. 9, 3049-3060 (2009)

Chiang, P.-C., Chiang, Y.-C., Chang, E.-E., Chang, S.-C.: Characteristics of polynuclear aromatic hydrocarbons in ambient air through a long-term sampling program at a metropolitan city in Taiwan. Aerosp. Sci. Technol. 37, 133-144 (2003)

Draxler, R.R., Rolph, G.D.: HYSPLIT (Hybrid Single-Particle Lagrangian Integrated Trajectory) Model access via NOAA ARL READY Website (http://www.arl.noaa.gov/ready/hysplit4.html), NOAA Air Resources Laboratory, Silver Spring, USA (2009)

Duan, J., Bi, X., Tan, J., Shen, G., Fu, J.: Seasonal variation on size distribution and concentration of PAHs in Guangzhou city, China. Chemosphere. 67, 614-622 (2007)

Finlayson-Pitts, B.J., Pitts Jr., J.N.: Chemistry of the upper and lower atmosphere. Academic, San Diego (1999) Guo, H., Lee, S.C., Ho, K.F., Wang, X.M., Zou, S.C.: Particle-associated polycyclic aromatic hydrocarbons in urban air of Hong Kong. Atmos. Environ. 37, 5307-5317 (2003)

International Agency for Research on Cancer: IRAC Monographs on the Evaluation of Carcinogenic Risks to Humans (http://monographs.iarc.fr/index.php), International Agency for Research on Cancer, Lyon, France (2009) 
Kalberer, M., Henne, S., Prevot, A.S.H., Steinbacher, M.: Vertical transport and degradation of polycyclic aromatic hydrocarbons in an Alpine Valley. Atmos. Environ. 38, 6447-6456 (2004)

Kaneyasu, N., Takada, H.: Seasonal variations of sulfate, carbonaceous species (black carbon and polycyclic hydrocarbons), and trace elements in fine atmospheric aerosols collected at subtropical islands in the East China Sea. J. Geophys. Res. (2004). doi:10.1029/2003JD004137

Kaneyasu, N., Koga, Takada, H., Kumata, H.: Studies on the Effects of Organic Aerosols on Regional and Global Climate, (1) Studies on the Transport and Radiative Forcing of Organic Aerosols, (2) Studies on Radiative Forcing of Organic Aerosols. In: Final Report of Global Environment Research Fund B-8 (in Japanese), pp. 19-33. The Ministry of the Environment of Japan, Tokyo (2005)

Kume, K., Ohura, T., Noda, T., Amagai, T., Fusaya, M.: Seasonal and spatial trends of suspended-particle associated polycyclic aromatic hydrocarbons in urban Shizuoka, Japan. J. Hazard. Mater. 144, 513-521 (2007)

Lang, C., Tao, S., Liu, W., Zhang, Y., Simonich, S.: Atmospheric transport and outflow of polycyclic aromatic hydrocarbons from China. Environ. Sci. Technol. 42, 5196-5201 (2008)

Lee, J.Y., Kim, Y.P., Kang, C.-H., Ghim, Y.S., Kaneyasu, N.: Temporal trend and long-range transport of particulate polycyclic aromatic hydrocarbons at Gosan in northeast Asia between 2002 and 2004. J. Geophys. Res. (2006). doi:10.1029/2005JD006537

Okuda, T., Naoi, D., Tenmoku, M., Tanaka, S., He, K., Ma, Y., Yang, F., Lei, Y., Jia, Y., Zhang, D.: Polycyclic aromatic hydrocarbons (PAHs) in the aerosol in Beijing, China, measured by aminopropylsilane chemically-bonded stationary-phase column chromatography and HPLC/fluorescence detection. Chemosphere 65, 427-435 (2006)

Park, S.S., Kim, Y.J., Kang, C.H.: Atmospheric polycyclic aromatic hydrocarbons in Seoul, Korea. Atmos. Environ. 36, 2917-2924 (2002)

Primbs, T., Simonich, S., Schmedding, D., Wilson, G., Jaffe, D., Takami, A., Kato, S., Hatakeyama, S., Kajii, Y.: Atmospheric outflow of anthropogenic semivolatile organic compounds from East Asia in Spring 2004. Environ. Sci. Technol. 41, 3551-3558 (2007)

Rogge, W.F., Hildemann, L.M., Mazurek, M.A., Cass, G.R., Simoneit, B.R.T.: Sources of fine organic aerosol. 2. Noncatalyst and catalyst-equipped automobiles and heavy-duty diesel trucks. Environ. Sci. Technol. 27, 636-651 (1993)

Sato, K., Tanaka, Y., Li, H., Ogawa, S., Hatakeyama, S.: Distributions and seasonal changes of organic aerosols at Cape Hedo, Okinawa: polycyclic aromatic hydrocarbons observed during 2005-2006. Chikyukagaku (in Japanese). 41, 145-153 (2007)

Simoneit, B.R.T., Kobayashi, M., Mochida, M., Kawamura, K., Lee, M., Lim, H.-J., Turpin, B.J., Komazaki, Y.: Composition and major sources of organic compounds of aerosol particulate matter sampled during the ACE-Asia campaign. J. Geophys. Res. (2004). doi:10.1029/2004JD004598

SKYNET project: SKYNET atmospheric radiation and weather observation network website (http://atmos.cr. chiba-u.ac.jp/), Chenter for Environmental Remote Sensing, Chiba University, Chiba, Japan (2009)

Takami, A., Miyoshi, T., Shimono, A., Kaneyasu, N., Kato, S., Kajii, Y., Hatakeyama, S.: Transport of anthropogenic aerosols from Asia and subsequent chemical transformation. J. Geophys. Res. (2007). doi:10.1029/2006JD008120

Tanaka, N., Sakata, M.: Effect of photooxidation on delta- ${ }^{13} \mathrm{C}$ of benzo(a)pyrene and benzo(e)pyrene in the atmosphere. Geochem. J. 36, 235-245 (2002)

Tang, N., Hattori, T., Taga, R., Igarashi, K., Yang, X., Tamura, K., Kakimoto, H., Mishukov, V.F., Toriba, A., Kizu, R., Hayakawa, K.: Polycyclic aromatic hydrocarbons and nitropolycyclic aromatic hydrocarbons in urban air particulates and their relationship to emission sources in the Pan-Japan Sea countries. Atmos. Environ. 39, 5817-5826 (2005)

Wang, G., Kawamura, K., Lee, S., Ho, K., Cao, J.: Molecular, seasonal, and spatial distributions of organic aerosols from fourteen Chinese cities. Environ. Sci. Technol. 40, 4619-4625 (2006)

Zhang, Y., Tao, S.: Global atmospheric emission inventory of polycyclic aromatic hydrocarbons (PAHs) for 2004. Atmos. Environ. 43, 812-819 (2009)

Zhang, Q., Jimenez, J.L., Canagaratna, M.R., Allan, J.D., Coe, H., Ulbrich, I., Alfarra, M.R., Takami, A., Middlebrook, A.M., Sun, Y.L., Dzepina, K., Dunlea, E., Docherty, K., DeCarlo, P.F., Salcedo, D., Onash, T., Jayne, J.T., Miyoshi, T., Shimono, A., Hatakeyama, S., Takegawa, N., Kondo, Y., Schneider, J., Drewnick, F., Borrmann, S., Weimer, S., Demerjian, K., Williams, P., Bower, K., Bahreini, R., Cottrell, L., Griffin, R.J., Rautiainen, J., Sun, J.Y., Zhang, Y.M., Worsnop, D.R.: Ubiquity and dominanance of oxygenated species in organic aerosols in anthropogenically-influenced northern hemisphere midlatitudes. Geophys. Res. Lett. (2007). doi:10.1029/2007GL029979

Zheng, M., Wan, T.S.M., Fang, M., Wang, F.: Characterization of the non-volatile organic compounds in the aerosols of Hong Kong-identification, abundance and origin. Atmos. Environ. 31, 227-237 (1997) 